\title{
Treatment of landfill leachate by immobilized Ganoderma australe and crude enzyme
}

\author{
Wan Abdul Razak Wan Razarinah ${ }^{\mathrm{a}, \mathrm{b}, *}$, Mahmood Noor Zalina ${ }^{\mathrm{a}}$, Noorlidah Abdullah ${ }^{\mathrm{a}}$ \\ a Mushroom Research Centre, University of Malaya, Faculty of Science, Institute of Biological Sciences, \\ 50603 Kuala Lumpur, Malaysia \\ b Faculty of Applied Sciences, University of Technology MARA, 40450 Shah Alam, Selangor, Malaysia
}

${ }^{*}$ Corresponding author, e-mail: razarina408@yahoo.com

\begin{abstract}
Landfill leachate is a complex environmental problem. Here, we used immobilized Ganoderma australe and crude enzyme to treat landfill leachate. The treatment by immobilized G. australe achieved $50 \%$ and $32 \%$ removals for leachate $\mathrm{BOD}_{5}$ and $\mathrm{COD}$, respectively. Totals of $58 \%, 57 \%$, and $62 \%$ of $\mathrm{BOD}, \mathrm{COD}$, and $\mathrm{NH}_{3}-\mathrm{N}$ percentage removal were obtained when the leachate previously treated with immobilized G. australe was continuously treated with crude enzymes. Using a continuous treatment with crude enzymes achieves higher percentages of COD and $\mathrm{NH}_{3}-\mathrm{N}$ removal.
\end{abstract}

KEYWORDS: white-rot fungi, municipal solid waste, biological oxygen demand, chemical oxygen demand

\section{INTRODUCTION}

Landfill leachate comprises a complex mixture of inorganic and organic substances. Landfills generate large amounts of leachates that contain high concentrations of organics and ammonia nitrogen ${ }^{1}$. Biological activity within the landfill influences its chemical composition ${ }^{2}$. Several options have been implemented to treat leachate, presenting varying degrees of efficiency. Biological treatment is often chosen due to its reliability, simplicity, and high costeffectiveness ${ }^{3}$. In addition, biological processes based upon suspended-growth biomass have been proved to be effective in removing organic carbon and nutrients content ${ }^{4}$. However, some problems have been encountered. The methods that use microbes for bioremediation are expensive and microbial cultures take a long time to produce ${ }^{5}$. For that reason, a good alternative is the use of immobilized cultures on supports ${ }^{6}$. Immobilized cultures tend to produce higher levels of enzymes and are more resistant to environmental changes, such as $\mathrm{pH}$ or toxic chemicals, than free cell cultures ${ }^{7}$.

Basidiomycetous white-rot fungi are capable of degrading a variety of environmental pollutants such as aromatic compounds. This capability arises from the production of powerful oxidative and non-specific extracellular enzymes known as peroxidases. The peroxidase families are best recognized by lignin peroxidases (LiP), manganese peroxidases (MnP), and aryl-alcohol oxidase ${ }^{8}$. Peroxidases and laccases have a broad substrate specificities and can catalyse the oxidation of a wide range of toxic organic compounds ${ }^{9}$. They can remain active in the presence of harsh living conditions such as recalcitrant and toxic xenobiotics in the leachate ${ }^{10}$. White-rot fungi are therefore a good potential to be applied in wastewater treatment, for example leachate.

Bioaugmentation is a biological method that involves the addition of microbial products such as enzymes to wastewater to accelerate the rate of pollutant degradation. Enzymes are classified broadly as hydrolytic, oxidizing, or reducing, depending on the type of reaction that they catalyse ${ }^{11}$. The transformation takes place as the enzyme encounter its substrate (the target pollutant) and splits it into component parts or removes part of the molecule. This process occurs very rapidly, leaving the enzyme unaltered and ready to react with further molecules of substrate. There are several benefits of using enzymes for environmental applications which include: (1) they can function either at mild, replacing harsh or work in extreme conditions, hence saving energy and preventing pollution; (2) they are highly specific, which results in less unwanted side effects and byproducts in the production process; (3) enzymes are also able to treat waste consisting of biological material; and (4) enzymes themselves are biodegradable, so they are readily absorbed back into nature ${ }^{12}$.

Enzymes are natural catalysts commonly found 
in all living organisms ${ }^{5}$. They may be used either for building more complex molecules from simple ones or for selective breakdown of a mixture of larger molecules. It was reported that over 1000 different enzymes consisting in just one microorganism ${ }^{12}$. Many reports demonstrate that the complex ligninolytic machinery of basidiomycetous fungi is involved in most degradation processes ${ }^{13}$. This enzymatic complex includes, among many others, enzymes such as lignin peroxidase, manganese peroxidase ${ }^{14}$, and laccase, which has been confirmed to be essential for ligninolytic activity in many white-rot fungi ${ }^{15}$. White-rot fungi have capacity to produce one or more extracellular lignin-modifying enzymes due to their lack of substrate specificity, hence are also capable of degrading a wide range of xenobiotics ${ }^{16}$. White-rot fungi such as Phanerochaete chrysosporium typically secrete one or more of the three principal ligninolytic enzymes, i.e., lignin peroxidase (LiP, EC 1.11.1.14), Mn-dependent peroxidase (MnP, EC 1.11.1.13) and phenol oxidase (Laccase) (LAC, EC 1.10.3.2) ${ }^{17}$. Hence this paper focused on treatment of landfill leachate using biological method by immobilized white-rot fungi, G. australe and bioaugmentation of crude enzymes to improve the performance of wastewater (e.g., leachate) treatment system and meet the discharge standards.

\section{MATERIALS AND METHODS}

\section{Fungi and subculture of fungi}

Ganoderma australe was obtained from the Mycology Laboratory, Institute of Biological Sciences, University of Malaya, Malaysia. The fungi were maintained on malt extract (Oxoid) agar (MEA) slants, and the inoculum was prepared by subculturing onto MEA grown for 7 days at $28 \pm 2{ }^{\circ} \mathrm{C}$. Subculture was done once a week to obtain active fungi.

\section{Mycelial suspension and immobilization of fungi on Ecomat}

Mycelial suspension: Four plugs ( $6 \mathrm{~mm}^{2}$ diameter) of a 7-day old fungal colony growing in MEA media in Petri plates were transferred into 250-ml Erlenmeyer culture flasks containing $100 \mathrm{ml}$ of glucoseyeast-malt-peptone (GYMP) growth medium under sterile conditions. The GYMP growth medium contained the following: $\mathrm{MgSO}_{4} \cdot 7 \mathrm{H}_{2} \mathrm{O}(1.00 \mathrm{~g} / \mathrm{l})$; $\mathrm{KH}_{2} \mathrm{PO}_{4}(1.00 \mathrm{~g} / \mathrm{l}) ; \mathrm{K}_{2} \mathrm{HPO}_{4}(1.00 \mathrm{~g} / \mathrm{l}) ; \quad \mathrm{NH}_{4} \mathrm{Cl}$ $(1.00 \mathrm{~g} / \mathrm{l})$; Glucose $(15.00 \mathrm{~g} / \mathrm{l})$; Peptone $(8.00 \mathrm{~g} / \mathrm{l})$; Yeast extract $(8.00 \mathrm{~g} / \mathrm{l})$; and Malt Extract $(8.00 \mathrm{~g} / \mathrm{l})$. Inoculated flasks were then agitated on an orbital shaker for $48 \mathrm{~h}$ at $28 \pm 2{ }^{\circ} \mathrm{C}$ at $150 \mathrm{rpm}$.
Ecomat sterilization: Fifty pieces of Ecomat were put into a $500 \mathrm{ml}$ beaker. The beaker was covered with aluminium foil and then sterilized in autoclave for $1 \mathrm{~h}$ prior to use. Ecomat is natural support material for immobilization of fungal mycelium. It is a high-tech organic fibres (lignocellulolytic fibres) made from $100 \%$ oil palm empty fruit bunches (manufactured by Ecofibre Technology, Malaysia) ${ }^{7}$.

Fungi immobilization on Ecomat: Four pieces of sterilized Ecomat and $5 \mathrm{ml}$ of mycelia suspension were added to 250-ml Erlenmeyer culture flasks containing $50 \mathrm{ml}$ of GYMP growth medium. The flasks were agitated at $100 \mathrm{rpm}$ on an orbital shaker. The Ecomat covered with fungal mycelium within 4 days were used for the study. The use of natural support materials in immobilization showed better colonization by fungal thus increase the attachment of mycelial biomass to the support materials ${ }^{18}$. Hence this can increase the degradation rate of pollutant by the fungal mycelium.

\section{Experimental design}

Leachate characterization before treatment: Leachate sample used in this study was collected from the pond of untreated leachate at the sanitary landfill. The leachate was filtered to remove suspended solids before analysis for $\mathrm{pH}$, chemical oxygen demand (COD), biological oxygen demand $\left(\mathrm{BOD}_{5}\right)$, and ammoniacal nitrogen $\left(\mathrm{NH}_{3}-\mathrm{N}\right)$ according to the Standard Method for the Examination of water and wastewater ${ }^{19}$ using a Hach DR 2800 spectrophotometer.

Leachate treatment by immobilized G. australe followed by treatment with crude enzymes: Experiments were carried-out in Erlenmeyer flask and consisted of two phases. In the first phase, in 250-ml Erlenmeyer culture flasks, $125 \mathrm{ml}$ of leachate was treated with immobilized G. australe on Ecomat. The flasks were then agitated on an orbital shaker for seven days at $28 \pm 2{ }^{\circ} \mathrm{C}$ at $150 \mathrm{rpm}$. Then, in the second phase, the treated leachate from the first phase was collected and subsequently treated with $10 \mathrm{U} / \mathrm{ml}$ of crude enzyme. The crude enzyme was cell-free enzyme (in a form of powder) isolated from their originating cells and might contain all enzymes produced by $G$. australe The crude enzyme was prepared by freeze-dried the extracellular enzymes produced by $G$. australe until it became powder. Extracellular enzymes produced by four-days old G. australe mycelium showed significant productivity of ligninolytic enzymes such as $\mathrm{MnP}$, laccase, and LiP, which are important enzymes for pollutant degradation ${ }^{7}$. The reaction mixture consists of $19.8 \mathrm{ml}$ of $50 \mathrm{mM}$ sodium citrate buffer 
Table 1 Percentage of $\mathrm{BOD}_{5}, \mathrm{COD}$, and $\mathrm{NH}_{3}-\mathrm{N}$ removal and $\mathrm{pH}$ changes in leachate.

\begin{tabular}{|c|c|c|c|c|c|c|c|}
\hline \multirow[b]{2}{*}{ Parameters } & \multirow[b]{2}{*}{$\begin{array}{l}\text { Levels in } \\
\text { untreated leachate }\end{array}$} & \multicolumn{2}{|c|}{ Immobilized $G$. australe only } & \multicolumn{2}{|c|}{ Crude enzyme only } & \multicolumn{2}{|c|}{$\begin{array}{l}\text { Immobilized } G \text {. australe } \\
\text { and crude enzymes }\end{array}$} \\
\hline & & $\begin{array}{l}\text { Levels in } \\
\text { treated leachate }\end{array}$ & $\begin{array}{l}\text { Percentage } \\
\text { of change }\end{array}$ & $\begin{array}{l}\text { Levels in } \\
\text { treated leachate }\end{array}$ & $\begin{array}{l}\text { Percentage } \\
\text { of change }\end{array}$ & $\begin{array}{l}\text { Levels in } \\
\text { treated leachate }\end{array}$ & $\begin{array}{c}\text { Percentage } \\
\text { of change* }\end{array}$ \\
\hline $\mathrm{BOD}_{5}(\mathrm{mg} / \mathrm{l})$ & 4166 & $2070 \pm 430$ & -50 & $1730 \pm 130$ & -16 & $1730 \pm 130$ & -58 \\
\hline $\mathrm{COD}(\mathrm{mg} / \mathrm{l})$ & 5980 & $4080 \pm 210$ & -32 & $2570 \pm 130$ & -37 & $2570 \pm 130$ & -57 \\
\hline $\mathrm{NH}_{3}-\mathrm{N}(\mathrm{mg} / \mathrm{l})$ & 30.9 & $43.2 \pm 5.2$ & +40 & $11.7 \pm 3.6$ & -73 & $11.7 \pm 3.6$ & -62 \\
\hline $\mathrm{pH}$ & 8.14 & $9.11 \pm 0.72$ & +12 & $8.87 \pm 0.74$ & -3 & $8.87 \pm 0.74$ & +9 \\
\hline
\end{tabular}

( $\mathrm{pH} 6.5), 2.0 \mathrm{ml}$ of crude enzyme (at $10 \mathrm{U} / \mathrm{ml}$ ), and $0.2 \mathrm{ml}$ of leachate. The combination of crude extract enzyme and leachate medium was incubated on an orbital shaker at $80 \mathrm{rpm}$ for $4 \mathrm{~h}$. All processes were done under sterile conditions at ambient temperature.

Determination of leachate characteristics after treatment: Removal of $\mathrm{BOD}, \mathrm{COD}$, and $\mathrm{NH}_{3}-\mathrm{N}$ were investigated after fungal treatment and the results were compared with the initial values.

\section{RESULTS}

The results obtained from the previous experiments demonstrated that treatment of leachate with immobilized $G$. australe on Ecomat only achieved significant $\mathrm{BOD}_{5}$ removal, while treatment of leachate with crude enzymes attained notable effect on $\mathrm{NH}_{3}-\mathrm{N}$ removal. For this reason, the treatment of the leachate using fungi was carried-out by combining the immobilized G. australe on Ecomat and crude enzymes. It consists of two phases where, in the first phase, the concentrated leachate was treated with the immobilized G. australe on Ecomat. Result of leachate remediation after the first phase showed that the percentage removal of leachate components obtained was $50 \%$ for $\mathrm{BOD}_{5}, 32 \%$ for $\mathrm{COD}$, and $-40 \%$ for $\mathrm{NH}_{3}-\mathrm{N}$ (Table 1).

At the second phase, the leachate was collected and treated with $10 \mathrm{U} / \mathrm{ml}$ of crude enzyme at $4 \mathrm{~h}$ of exposure on an orbital shaker at $80 \mathrm{rpm}$. After the second phase of experiments, $16 \%, 37 \%$, and $73 \%$ of $\mathrm{BOD}_{5}, \mathrm{COD}$, and $\mathrm{NH}_{3}-\mathrm{N}$ removal were achieved, respectively (Table 1). Finally, by the end of the experiment, the percentage removal of leachate components was enhanced (Table 1). Overall, after the concurrent treatment with immobilized $G$. australe and crude enzymes, $58 \%, 57 \%$, and $62 \%$ percentage removal of leachate $\mathrm{BOD}_{5}, \mathrm{COD}$, and $\mathrm{NH}_{3}-\mathrm{N}$ were achieved, respectively. Meanwhile, the $\mathrm{pH}$ at both phases of the experiment was not much different with the value of 9.11 after the first phase of experiment and 8.87 at the end of second phase of the experiment.

\section{DISCUSSION}

The treatment of concentrated leachate by immobilized $G$. australe followed by treatment with crude enzyme revealed that the first phase of treatment which is by immobilized $G$. australe on Ecomat only exhibited $50 \%$ and $32 \%$ of $\mathrm{BOD}_{5}$ and COD removal, respectively. The results obtained show that white-rot fungi $G$. australe is capable of removing $\mathrm{BOD}_{5}$ and $\mathrm{COD}$, but not $\mathrm{NH}_{3}-\mathrm{N}$. White-rot fungus P. chrysosporium has been used for the biological removal of organics measured as $\mathrm{COD}^{20}$. Whiterot fungi have been attracting a growing interest for the biotreatment (removal or destruction) of waste water ingredients such as metals, inorganic nutrients, and organic compound due to their ability to adapt to severe environmental constraints ${ }^{21,22}$. Based on this finding, white-rot fungi $G$. australe demonstrated effectiveness for organic removal in leachate treatment $^{23,24}$. Furthermore, immobilization of fungal biomass can increase the degradation capacity and the tolerance to toxic pollutant concentrations. This is due to the fact that using an immobilized system provides greater degree of stability for the fungi and a high tolerance for elevated pollutant concentrations ${ }^{25}$. In addition, immobilization of mycelia can enhance enzyme production by facilitating mycelia-fluid contact; hence improving the mass and $\mathrm{O}_{2}$ transfer rates ${ }^{26,27}$. Previous result showed that $G$. australe was able to produce ligninolytic enzymes such as LiP, MnP, and laccase $^{7}$. These enzymes are known for their ability to degrade a variety of environmental pollutants including leachate ${ }^{8}$.

The continuous experiment with only $10 \mathrm{U} / \mathrm{ml}$ of crude enzyme at $4 \mathrm{~h}$ exposure on an orbital shaker at $80 \mathrm{rpm}$ not only could remove $\mathrm{BOD}_{5}$ and COD but also $\mathrm{NH}_{3}-\mathrm{N}$. The percentage removal achieved were $58 \%, 57 \%$, and $62 \%$ for leachate $\mathrm{BOD}_{5}, \mathrm{COD}$, and $\mathrm{NH}_{3}-\mathrm{N}$, respectively. These results show that enzyme can be applied to remove leachate $\mathrm{NH}_{3}-\mathrm{N}$ significantly. They also show the ability to remove $\mathrm{BOD}_{5}$ and COD. The ability of these enzymes to degrade a variety of industrial pollutants, environ- 
mental pollutants, and leachate was also supported by the previous studies ${ }^{4,28}$. Ligninolytic enzymes that produced by $G$. australe are haemoproteins with an exceptional broad substrate spectrum that include organic and inorganic compounds. These enzymes can catalyse oxidations and resulting in the formation of free radicals (e.g., phenoxyl and aryl cation radicals), reactive cations, (e.g., $\mathrm{Mn}^{3+}$ ), or anions (e.g., $\mathrm{OCl}^{-}$) which are involved in the destruction of humic substances, the oxidation of toxic compounds, and nonspecific defence reactions ${ }^{26}$.

Treatment of leachate by immobilized $G$. australe followed by treatment with crude enzyme demonstrated that removal of leachate $\mathrm{NH}_{3}-\mathrm{N}$ only occurred when leachate was treated with crude enzymes (cellfree enzyme). This may be due to the very slow transformation of $\mathrm{NH}_{3}-\mathrm{N}$ into soluble or easily cellavailable products. On the contrary, removal of leachate $\mathrm{BOD}_{5}$ was significantly obtained when immobilized $G$. australe was applied while, COD removal could be obtained with both by immobilized of G. australe or crude enzymes. These findings suggested to achieve optimum removal of leachate $\mathrm{BOD}_{5}, \mathrm{COD}$ and $\mathrm{NH}_{3}-\mathrm{N}$, combination treatment of immobilized G. australe and crude enzymes must be applied.

Acknowledgements: This study was financially supported by University of Malaya grant No. IPPP PS148/ 2009A.

\section{REFERENCES}

1. Ellouze M, Aloui F, Sayadi S (2009) Effect of high ammonia concentrations on fungal treatment of Tunisian landfill leachates. Desalination 246, 468-77.

2. El-Fadel M, Bou-Zeid E, Chahine W, Alayli B (2002) Temporal variation of leachate quality from pre-sorted and baled municipal solid waste with high organic and moisture content. Waste Manag 22, 269-89.

3. Kalčíková G, Babič J, Pavko A, Gotvajn AZ (2014) Fungal and Enzymatic treatment of mature municipal landfill leachate. Waste Manag 34, 798-803.

4. Zouboulis AI, Loukidou MX, Christodoulou K (2001) Enzymatic treatment of sanitary landfill leachate. Chemosphere 44, 1103-8.

5. Ahuja SK, Ferreira GM, Moreira AR (2004) Utilization of enzymes for environmental applications. Crit Rev Biotechnol 24, 125-54.

6. Spina F, Anastasi A, Prigione V, Tigini V, Varese GC (2012) Biological treatment of industrial wastewaters: a fungal approach. Chem Eng Trans 27, 175-80.

7. Abdullah N, Wan Razarinah WAR, Noor Zalina M, Taha RM (2013) Treatment of landfill leachate using Ganoderma australe mycelia immobilized on Ecomat. Int J Environ Sci Dev 4, 483-7.
8. Yateem A, Balba MT, Al-Awadhi N (1998) White rot fungi and their role in remediating oil-contaminated soil. Environ Int 24, 181-7.

9. Torres E, Bustos-Jaimes I, Le Borgne S (2003) Potential use of oxidative enzymes for the detoxification of organic pollutants. Appl Catal B 46, 1-15.

10. Tigini V, Spina F, Romagnolo A, Prigione V, Varese GC (2013) Effective biological treatment of landfill leachates by means of selected white rot fungi. Chem Eng Trans 32, 265-70.

11. Trombly J (1995) Engineering enzymes for better bioremediation. Environ Sci Tech 29, 560-4.

12. Novo Nordisk (1995) Enzymes at Work. Novo Nordisk A/S, Bagsværd, Denmark.

13. Eugenio ME, Carbajo JM, Terrón MC, González AE, Villar JC (2008) Bioremediation of lignosulphonates by lignin-degrading basidiomycetous fungi. Bioresour Tech 99, 4929-34.

14. Leonowicz A, Matuszewska A, Luterek J, Ziegenhagen D, Wojtaś-Wasilewska M, Cho NS, Hofrichter M, Rogalski J (1999) Biodegradation of lignin by white rot fungi. Fungal Genet Biol 27, 175-85.

15. Leonowicz A, Wojtas-Wasilewska M, Rogalski J, Luterek J (1991) Higher fungi as a potential feed and food source from lignocellulosic wastes. In: Blažej A, Prívarová V (eds) Environmental Biotechnology. Elsevier. pp 229-55.

16. Wesenberg D, Kyriakides I, Agathos SN (2003) Whiterot fungi and their enzymes for the treatment of industrial dye effluents. Biotechnol Adv 22, 161-87.

17. Gold MH, Alic M (1993) Molecular biology of the lignin-degrading basidiomycete Phanerochaete chrysosporium. Microbiol Rev 57, 605-22.

18. Low JYS, Abdullah N, Vikineswary S (2009) Evaluation of support materials for immobilization of Pycnoporus sanguineus mycelia for laccase production and biodegradation of polycyclic aromatic hydrocarbons. Res J Environ Sci 3, 357-66.

19. APHA (1998) Standard Methods for the Examination of Water and Wastewater, 20th edn, American Public Health Association, Washington, DC.

20. Kim YK, Park SK, Kim SD (2003) Treatment of landfill leachate by white rot fungus in combination with zeolite filters. J Environ Sci Health A 38, 671-83.

21. Walter M, Boyd-Wilson K, Boul L, Ford C, McFadden D, Chong B, Pinfold J (2005) Field-scale bioremediation of pentachlorophenol by Trametes versicolor. Int Biodeter Biodegr 56, 51-7.

22. Coulibaly L, Gourene G, Agathos NS (2003) Utilization of fungi for biotreatment of raw wastewaters. Afr $J$ Biotechnol 2, 620-30.

23. Saetang J, Babel S (2012) Biodegradation of organics in landfill leachate by immobilized white rot fungi, Trametes versicolor BCC 8725. Environ Tech 33, 2575-84.

24. Saetang J, Babel S (2010) Fungi immobilization for landfill leachate treatment. Water Sci Tech 62, 1240-7. 
25. Ehlers GA, Rose PD (2005) Immobilized white-rot fungal biodegradation of phenol and chlorinated phenol in trickling packed-bed reactors by employing sequencing batch operation. Bioresour Tech 96, 1264-75.

26. Mtui GYS (2012) Lignocellulolytic enzymes from tropical fungi: Types, substrates and applications. Sci Res Essays 7, 1544-55.

27. Mtui G, Nakamura Y (2002) Continuous production of lignin-degrading enzymes by Bjerkandera adusta immobilized on polyurethane foam. Biotechnol Lett 24, 1743-7.

28. Ikehata K, Buchanan ID, Smith DW (2004) Recent developments in the production of extracellular fungal peroxidases and laccases for waste treatment. J Environ Eng Sci 3, 1-19. 